\title{
Luna Moth, Actias (=Tropaea) Iuna (Linneaus) (Insecta: Lepidoptera: Saturniidae: Saturniinae) ${ }^{1}$
}

Donald W. Hall ${ }^{2}$

\section{Introduction}

The luna moth, Actias luna (Linnaeus), is arguably our most beautiful moth. Examples of its popularity include its appearance on a first class U.S. postage stamp issued in 1987; its selection to grace the front cover of A Field Guide to Moths of Eastern North America (Covell 2005); and the use of an animated luna moth in the current (2007) television commercials for the sleep aid Lunesta.

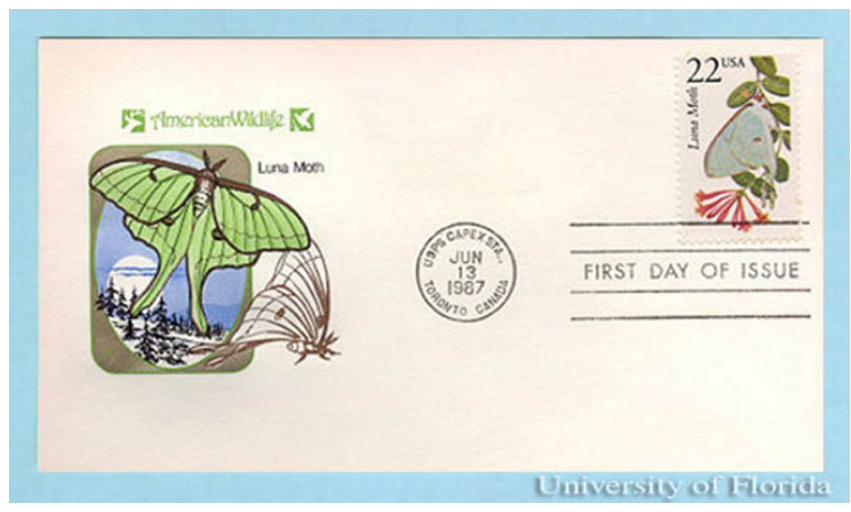

Figure 1. In 1987, the United States Post Office issued a first class stamp with the image of the luna moth, Actias Iuna (Linnaeus). Credits: D.W. Hall, University of Florida
Described and named (as Phalena plumata caudata) by Petiver in 1700 , the luna moth was the first North American saturniid to be reported in the literature (Tuskes et al. 1996). The original Latin name of the luna moth which referred to the long tails was lost when Linnaeus converted the name to a binomial with the specific epithet luna in 1758 .

The family name Saturniidae is based on the eyespots of some members of the family that contain concentric rings reminiscent of the planet Saturn (Powell 2003). The luna moth gets its name from its moon-like spots.

\section{Distribution}

Usually found in forested areas. In southern Canada it occurs from Nova Scotia to Saskatchewan. In the U.S., it is found in every eastern state from Maine south to Florida and west to eastern Texas and eastern North Dakota.

\section{Description}

Adults: The adult wingspan is 75 to $105 \mathrm{~mm}$ (Covell 2005). Adult luna moths are large green

1. This document is EENY-411 (IN737), one of a series of Featured Creatures from the Entomology and Nematology Department, Florida Cooperative Extension Service, Institute of Food and Agricultural Sciences, University of Florida. Published: June 2007. This document is also available on Featured Creatures Website at http://creatures.ifas.ufl.edu. Please visit the EDIS Website at http://edis.ifas.ufl.edu.

2. Donald W. Hall, professor, Entomology and Nematology Department, Institute of Food and Agricultural Sciences, University of Florida, Gainesville, FL 32611 .

The Institute of Food and Agricultural Sciences (IFAS) is an Equal Opportunity Institution authorized to provide research, educational information and other services only to individuals and institutions that function with non-discrimination with respect to race, creed, color, religion, age, disability, sex, sexual orientation, marital status, national origin, political opinions or affiliations. U.S. Department of Agriculture, Cooperative Extension Service, University of Florida, IFAS, Florida A. \& M. University Cooperative Extension Program, and Boards of County Commissioners Cooperating. Larry Arrington, Dean 
moths with a long tail on each hind wing and discal eyespots on both the fore and hind wings. The luna moth is univoltine (one generation) from Michigan northward, bivoltine throughout the Ohio Valley, and trivoltine southward (Tuskes et al. 1996). In Louisiana and Florida, adults may be found during every month of the year Also, reared specimens often differ in coloration from those in nature (Ferguson 1972).

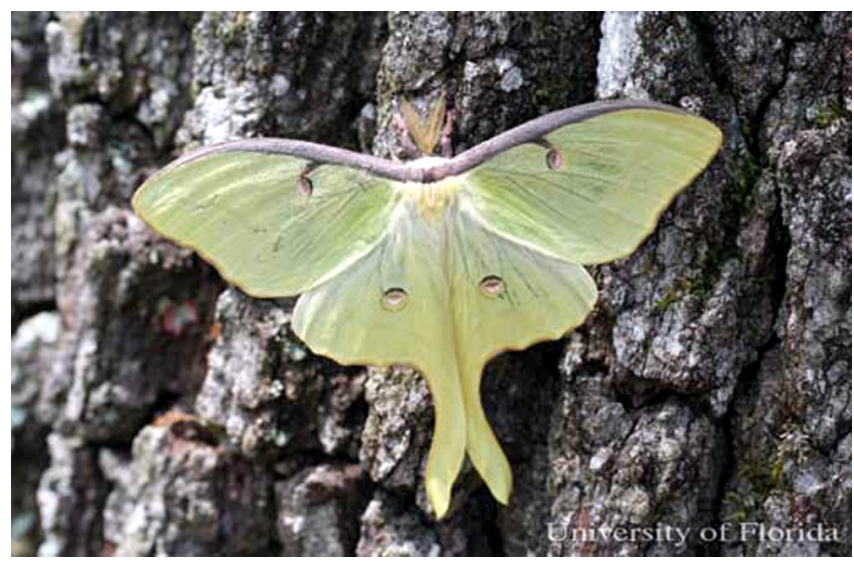

Figure 2. Adult male luna moth, Actias luna (Linnaeus). Credits: D.W. Hall, University of Florida

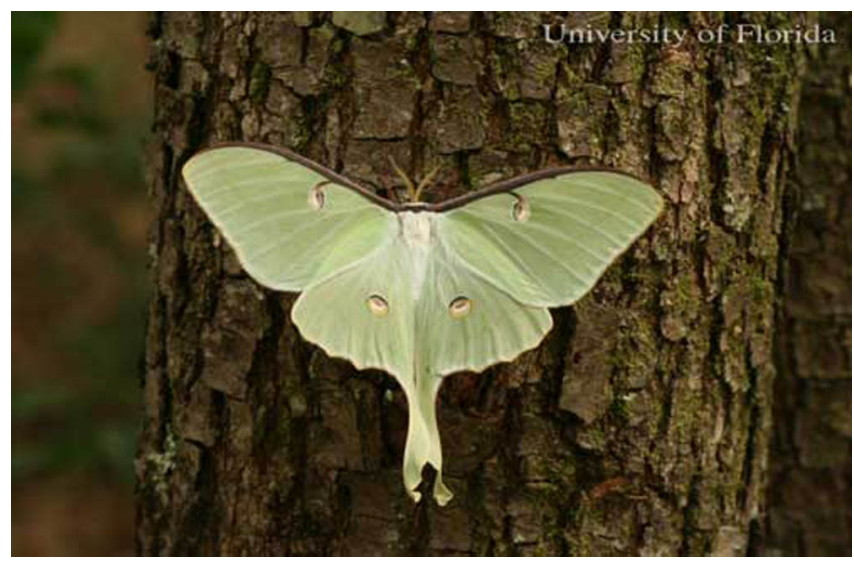

Figure 3. Adult female luna moth, Actias luna (Linnaeus). Credits: L.J. Buss, University of Florida

Adults of the spring brood in multivoltine (two or more generations) populations are typically a deeper green with reddish-purple wing margins while those of later broods are more yellowish with yellowish margins (Packard 1914, Tuskes et al. 1996). Moths from southern populations tend to be smaller.

Luna antennae are quadripectinate (comb-like on four sides) with those of males being larger than those of females. Males are more yellowish-green while females are more blue-green in color (Packard 1914).

Eggs: The slightly oval eggs are white, mottled with the brown adhesive. Maximum reported dimensions in millimeters are $1.9 \times 1.6 \times 1.2$ (length $\mathrm{x}$ width $\mathrm{x}$ height) (Peterson 1965).

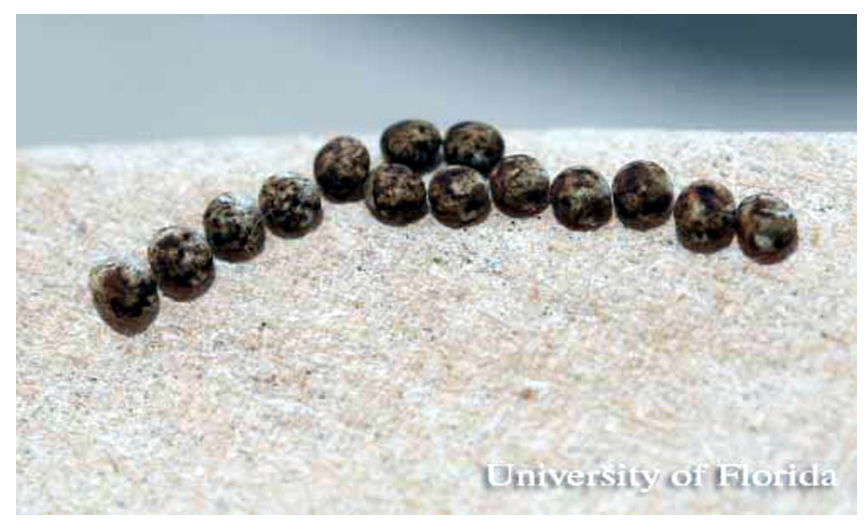

Figure 4. Eggs of the luna moth, Actias luna (Linnaeus). Credits: D.W. Hall, University of Florida

Larvae: The bright green full-grown caterpillars are 55 to $70 \mathrm{~mm}$ in length (Godfrey et al. 1987). There is a yellowish-white sub-spiracular line on abdominal segments one through seven and posterior yellow lines extending across the dorsum of segments one through seven to just above the level of the spiracles. A mid-segmental transverse band of setae-bearing scoli occurs on all thoracic segments and abdominal segments one through eight. The body is sparsely covered with short, white, spatulate setae. The head varies from green to brown. Just prior to pupation, caterpillars turn a reddish color.

Early instars differ considerably in appearance from the later instars. Packard (1914) provides color drawings and detailed descriptions of each of the five larval instars, but it should be noted that there is some variation in larvae from the same egg batch as well as considerable variation in larvae from different populations. Larvae of all instars reared by the author differ markedly in appearance from those illustrated by Packard. Some fifth instars are considerably more setiferous (hairy) than others even among siblings (see figures below). Packard (1914) gave the following lengths for the five instars: 1st instar: 6 to $8 \mathrm{~mm}$, 2nd instar: 9 to $10 \mathrm{~mm}$, 3rd instar: 13 to $15 \mathrm{~mm}$, 4th instar: $23 \mathrm{~mm}$, 5th instar: $65 \mathrm{~mm}$. 


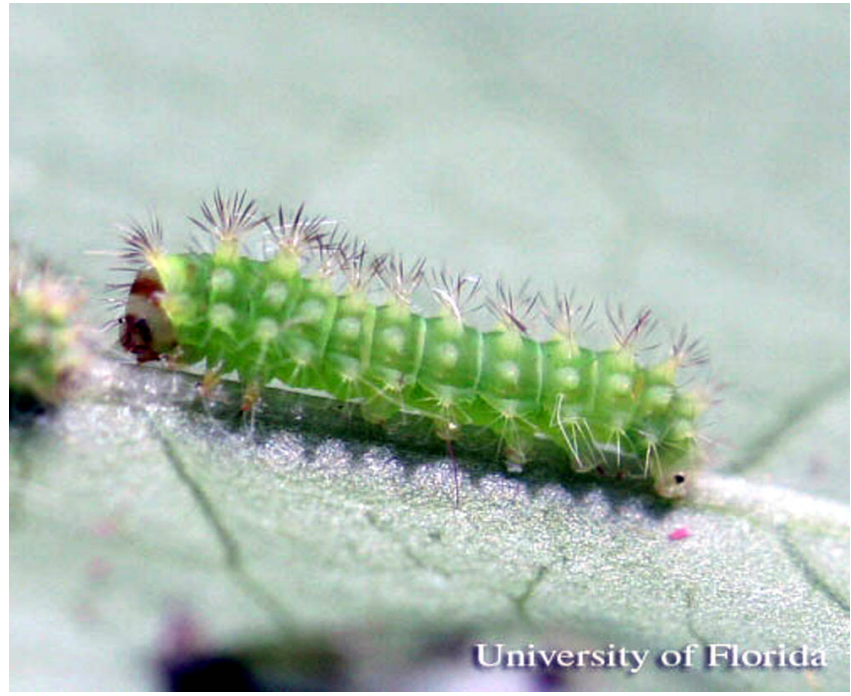

Figure 5. First instar larva of the luna moth, Actias luna (Linnaeus). Credits: D.W. Hall, University of Florida

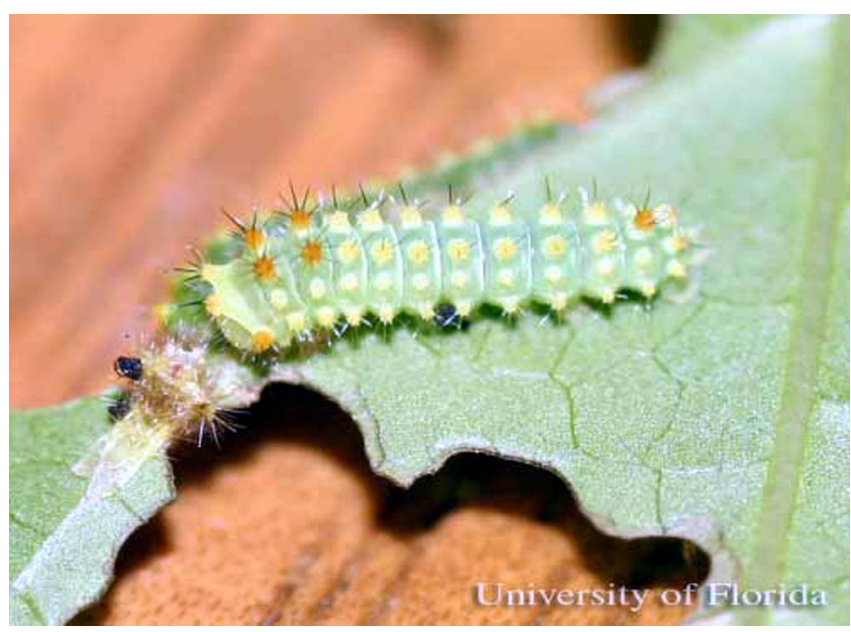

Figure 6. Second instar larva of the luna moth, Actias luna (Linnaeus). Credits: D.W. Hall, University of Florida

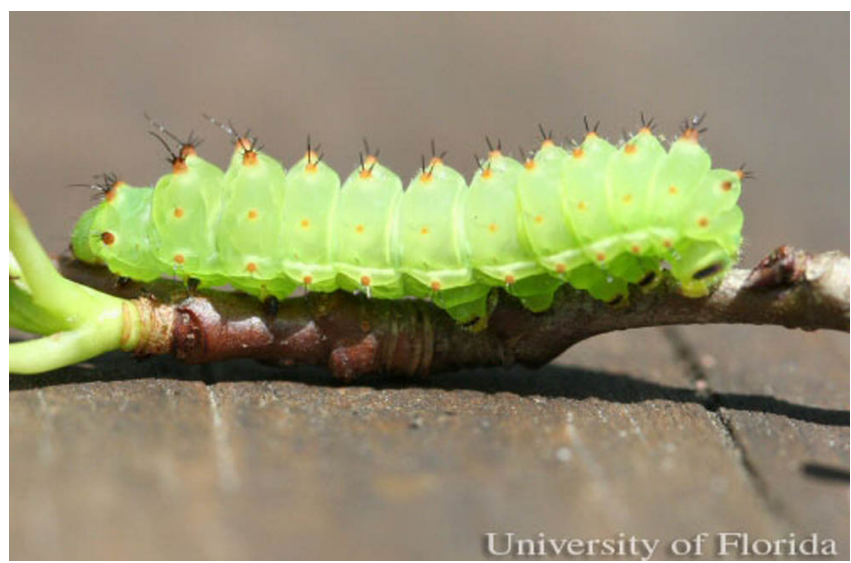

Figure 7. Third instar larva of the luna moth, Actias luna (Linnaeus). Credits: D.W. Hall, University of Florida

Cocoon and Pupa: The single-layered cocoon is wrapped in leaves. The dark brown, posterior end of

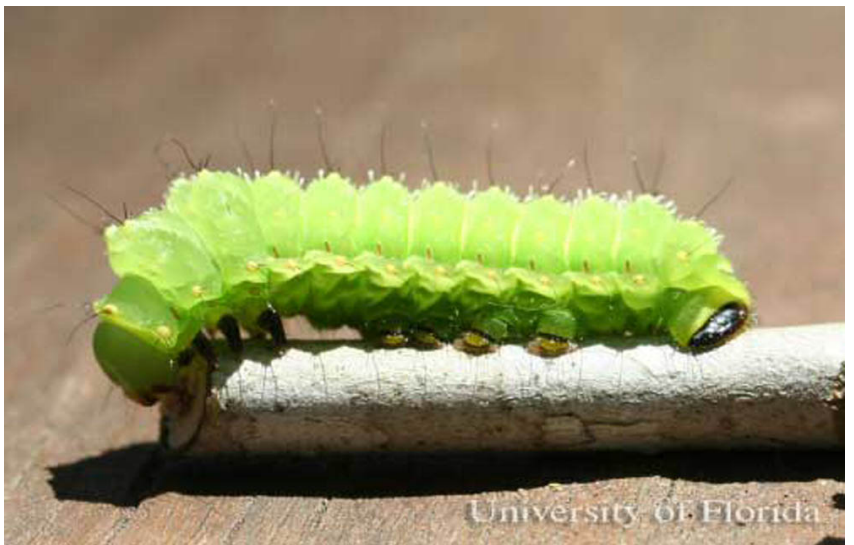

Figure 8. Fourth instar larva of the luna moth, Actias luna (Linnaeus). Credits: D.W. Hall, University of Florida

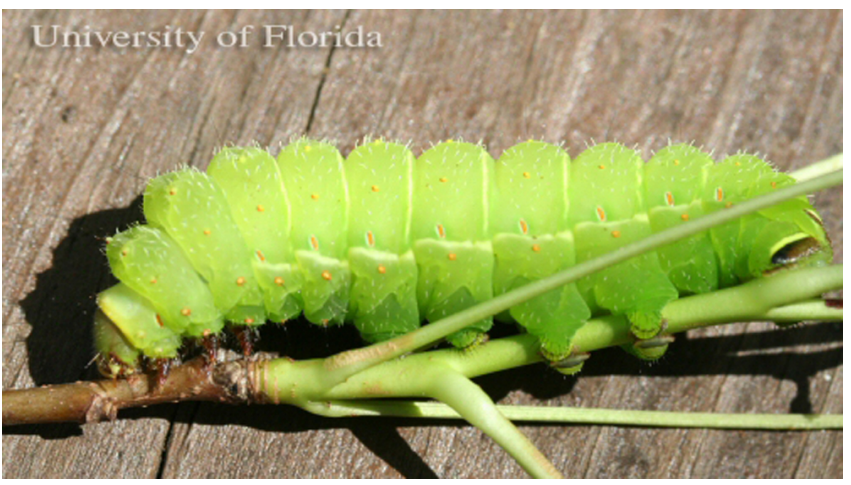

Figure 9. Fifth (last) instar larva of the luna moth, Actias Iuna (Linnaeus). Credits: D.W. Hall, University of Florida

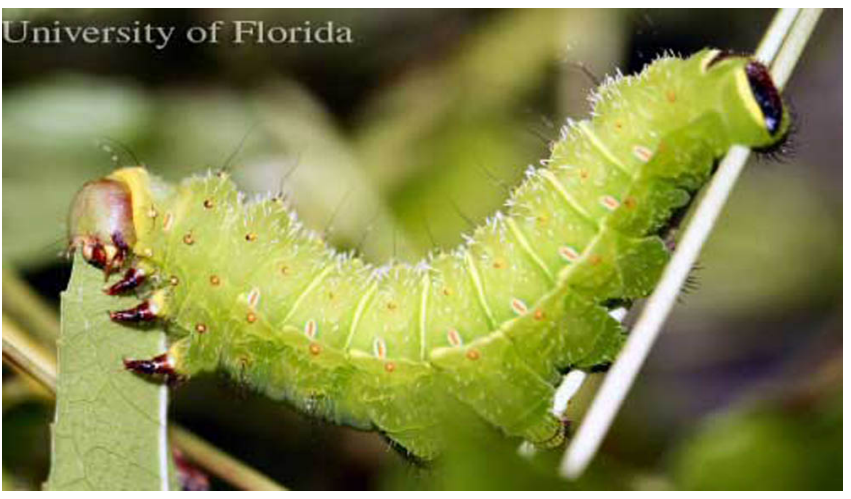

Figure 10. Fifth (last) instar larva (more sertiferous) of the luna moth, Actias luna (Linnaeus). Credits: D.W. Hall, University of Florida

the obtect (wings and appendages are appressed to the body - most abdominal segments are immovable) pupa is anchored to a pad of silk at the rear of the cocoon by a cremaster (hooked spines) which allows the adult to emerge from the pupal exoskeleton.

Female pupae may be distinguished from males by the presence of two longitudinal notches on the 


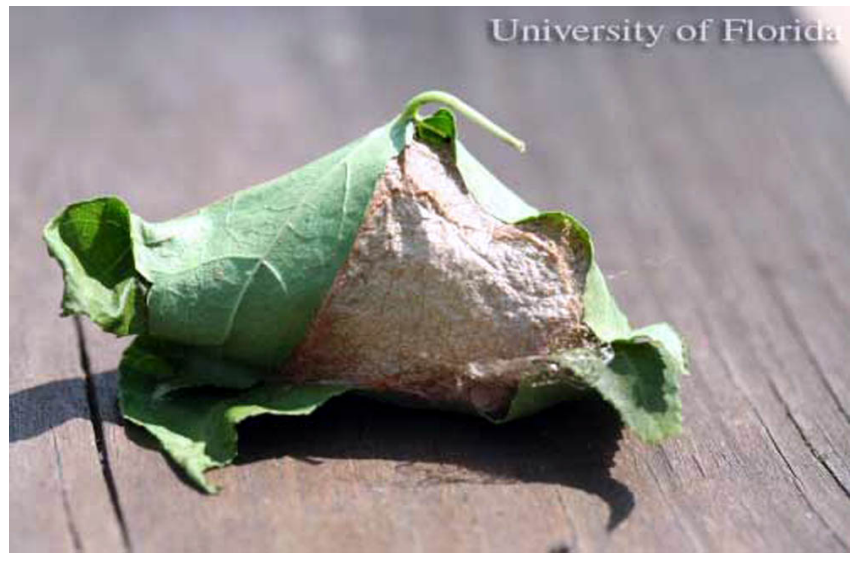

Figure 11. Cocoon of the luna moth, Actias luna (Linnaeus). Credits: D.W. Hall, University of Florida

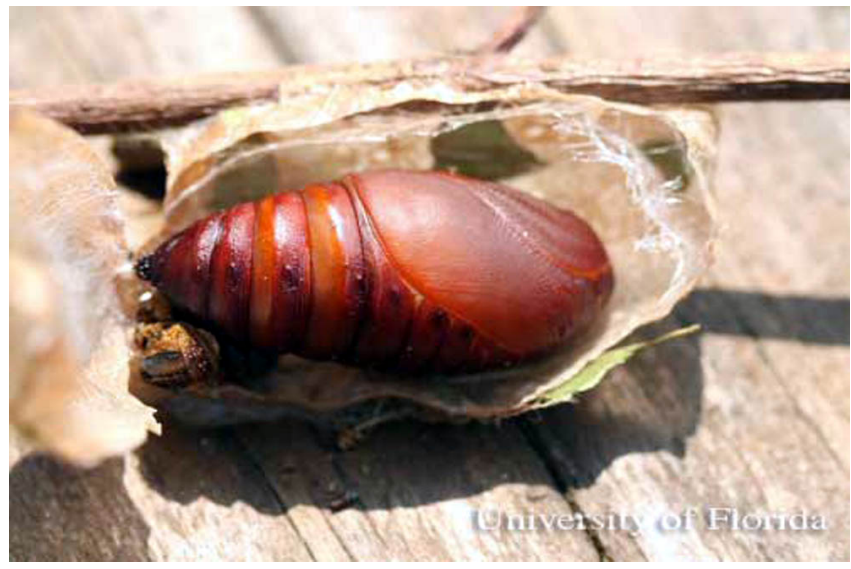

Figure 12. Pupa of the luna moth, Actias luna (Linnaeus). Lateral view. Credits: D.W. Hall, University of Florida

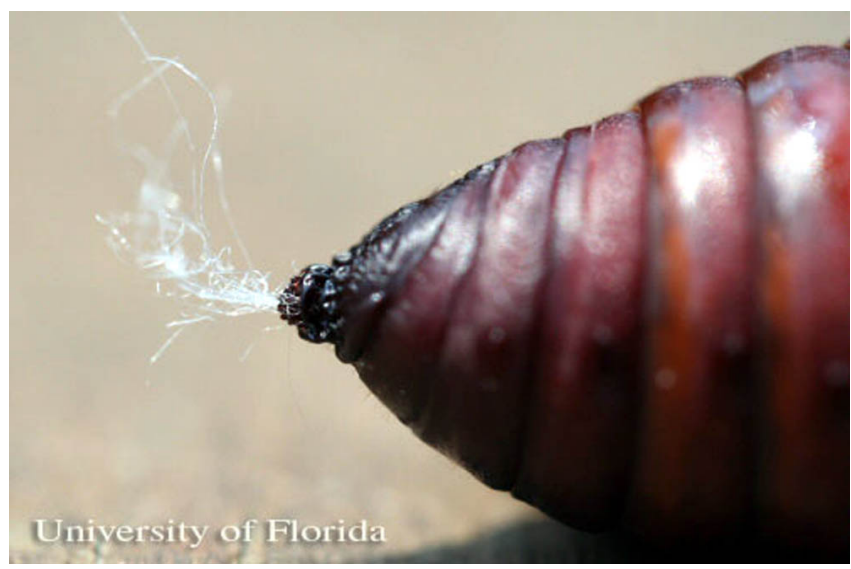

Figure 13. Pupa of the luna moth, Actias luna (Linnaeus). Credits: D.W. Hall, University of Florida

ventral surface of the fourth and fifth totally exposed abdominal segments. These notches are lacking in males.

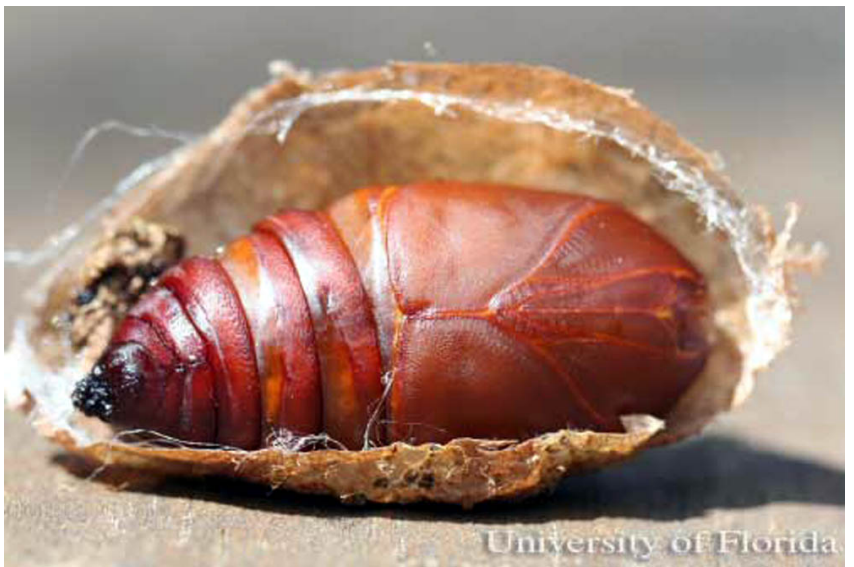

Figure 14. Female pupa of the luna moth, Actias luna (Linnaeus). Note the two longitudinal notches on the ventral surface of the fourth and fifth totally exposed abdominal segments Credits: D.W. Hall, University of Florida

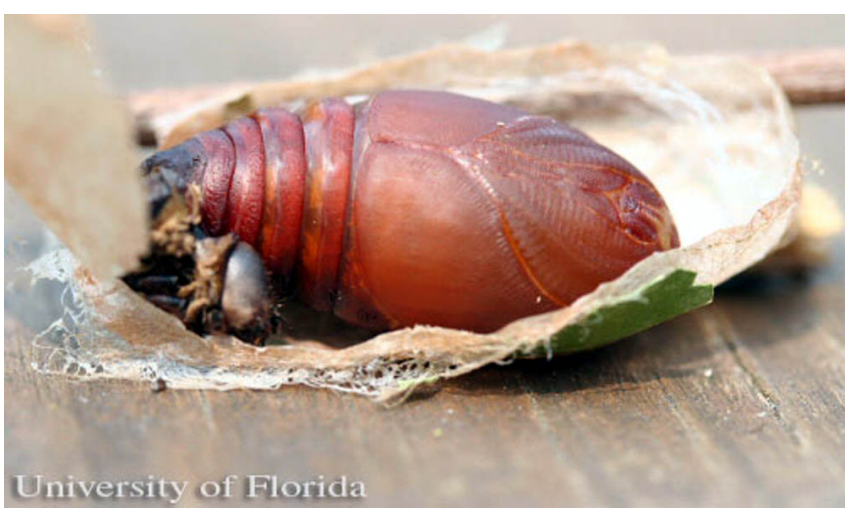

Figure 15. Male pupa of the luna moth, Actias luna (Linnaeus). Credits: D.W. Hall, University of Florida

\section{Life Cycle and Biology}

The adult moth escapes the pupal case by splitting it at the anterior end and pushing the top up. It then cuts its way from the cocoon by the use of serrated, chitinous spurs on its thorax near the bases of the front wings (Hilton 1965, Priddle 1967).

Adult eclosion (emergence from pupa) typically occurs in the morning with males usually beginning emergence several days before females. Morning emergence allows time for expansion and drying of the wings prior to the evening flight period. Also, during the first day after emergence, the moth voids the reddish-colored, liquid meconium which is composed of the breakdown waste products of the old larval tissues. 


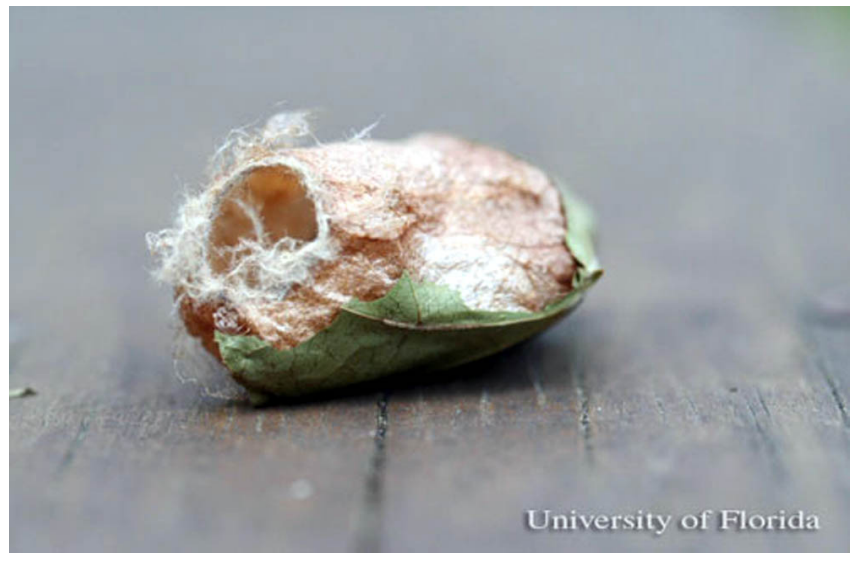

Figure 16. Emergence (exit) hole in cocoon of the luna moth, Actias luna (Linnaeus). Credits: D.W. Hall, University of Florida

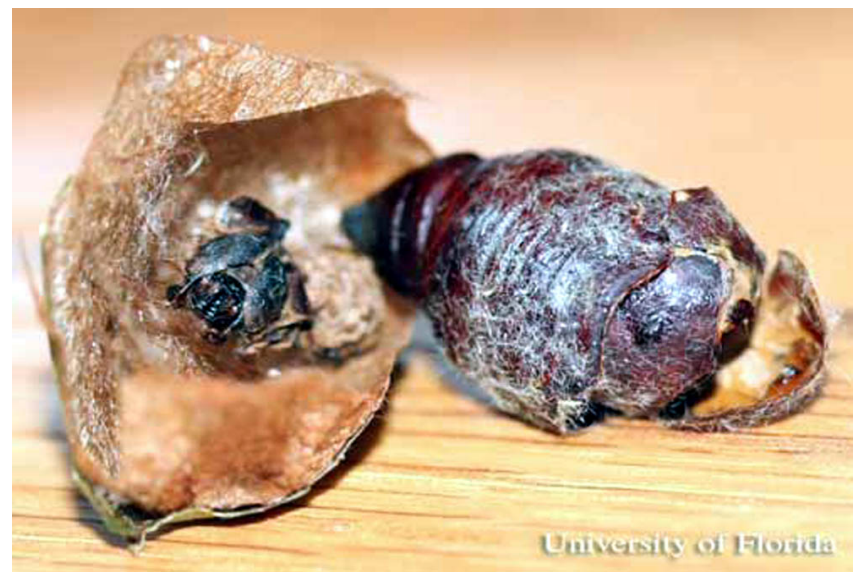

Figure 17. Cut away of cocoon with split pupal exuvium of the luna moth, Actias luna (Linnaeus). Credits: D.W. Hall, University of Florida

The adults are strongly attracted to light particularly UV wavelengths. There has been some concern that light pollution from man-made sources (particularly mercury vapor street lights) may deter lunas and other silk moths from mating and have a negative impact on their populations in urban areas (Worth and Muller 1979).

Males are strong fliers and may disperse over relatively long distances. Females release a sex-attractant pheromone and may attract males from a distance. Mating usually takes place during the first couple of hours after midnight. Adults have vestigial mouthparts and do not feed. Therefore, they are short-lived. Females begin laying eggs the following evening after mating and continue for several nights (Tuskes et al. 1996). At least in captivity and probably also in nature, the eggs may be laid either singly or in small clusters.
Caterpillars are solitary (Tuskes et al. 1996) and develop through five instars. Caterpillars exposed to short photoperiods produce diapausing pupae while those exposed to long photoperiods produce non-diapausing pupae (Wright 1967).

Broadleaf host plants belonging to a large number of genera have been reported as hosts for luna moths (Godfrey et al. 1987, Tietz 1972). However, some of the reported host plants may not be suitable for all populations of lunas. Lindroth et al. (1989) studied first instar survival, duration of larval stage, and pupal weights of caterpillars fed on eleven different plant species and found that survival was poor on some plant species that were reported in the literature as hosts. It appears that different geographical populations of luna moths are adapted to different host plants (Lindroth et al. 1989, Tuskes et al. 1996). Lindroth et al. (1989) suggested that biochemical detoxification of host defensive chemicals by caterpillar enzymes may be a factor in this host plant specialization.

Northernmost populations most often utilize white birch, Betula papyrifera Marsh, as a host. More southerly populations use a variety of host plants particularly members of the walnut family Juglandaceae (walnuts [Juglans] and hickories, [Carya]); sumacs (Rhus); sweetgum, Liquidambar styraciflua L.; and persimmon, Diospyros virginiana L. (Tuskes et al. 1996). Villard (1975) lists hickory as the preferred host, but recommends that rearing be done in sleeves or cages on living plants since most hickories wilt rapidly when cut. This obstacle can be overcome by diligently supplying fresh food.

Sweetgum works well for captive rearing.

Luna caterpillars are hosts for a number of insect parasitoids in the families Tachinidae, Ichneumonidae, and Pteromalidae (Tuskes et al. 1996, Kellog et al. 2003). All luna moth stages also are subject to predation by a variety of invertebrates and/or vertebrate predators. The adults are not even safe at night. Kellog et al. (2003) reported that the ground below an owl roost was littered with saturniid wings including those of luna moths.

Luna caterpillars gain protection from predators by their cryptic green coloration. When threatened they often rear the front part of the body in a "sphinx" 


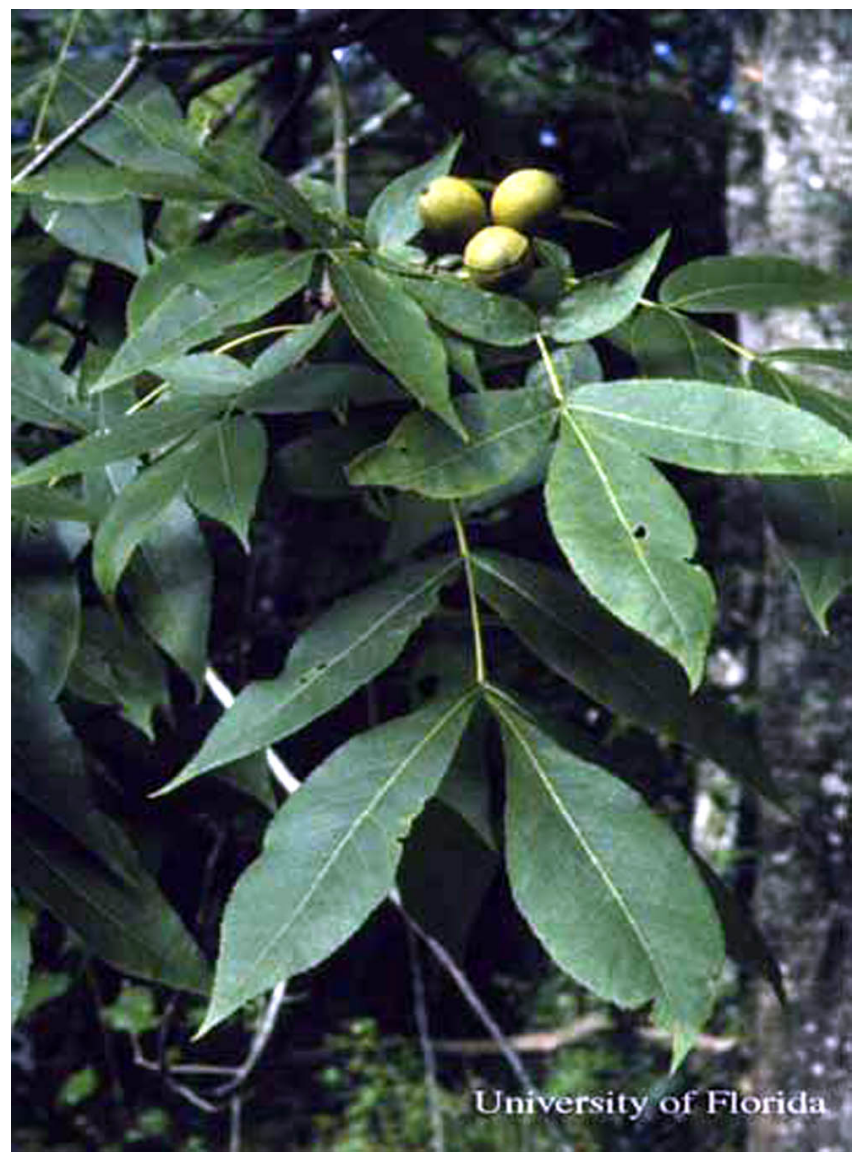

Figure 18. Pignut hickory, Carya glabra (Mill.)Sweet, a host of the luna moth, Actias luna (Linnaeus). Credits: D.W. Hall, University of Florida

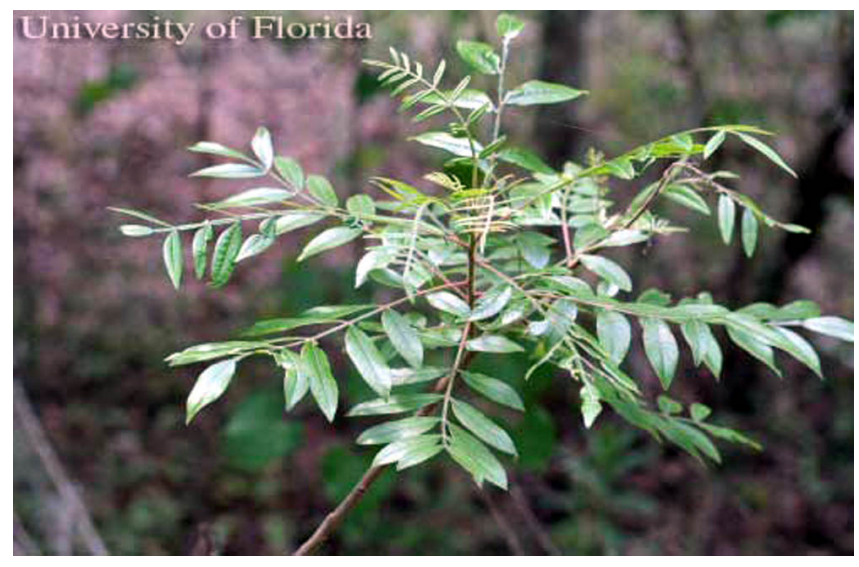

Figure 19. Winged sumac, Rhus copallinum L., a host of the luna moth, Actias luna (Linnaeus). Credits: D.W. Hall, University of Florida

pose - possibly to make them less caterpillar-like to a predator. If attacked, luna caterpillars as well as those of many other bombycoid moths make a clicking noise with the mandibles - sometimes as a prelude to or accompanied by defensive regurgitation of distasteful fluids. Brown et al. (2007) found that

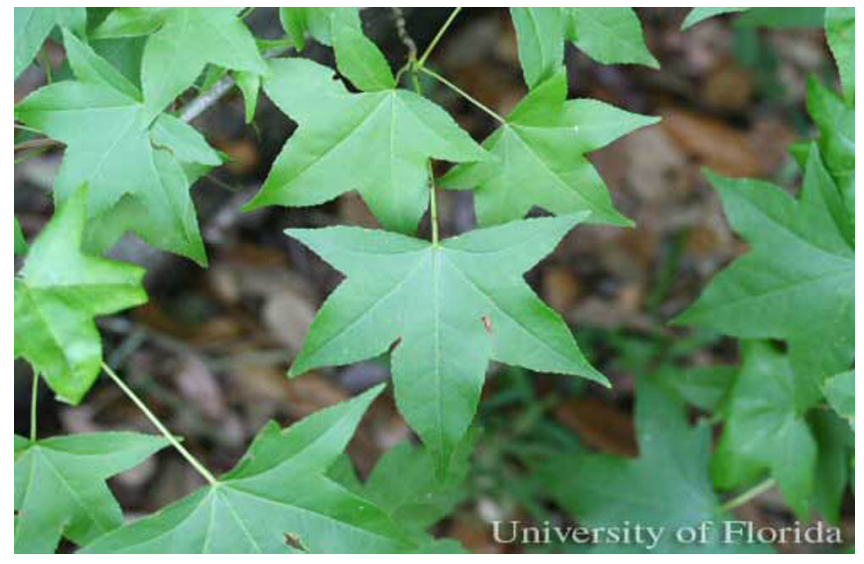

Figure 20. Sweetgum, Liquidambar styraciflua L., a host of the luna moth, Actias luna (Linnaeus). Credits: D.W. Hall, University of Florida

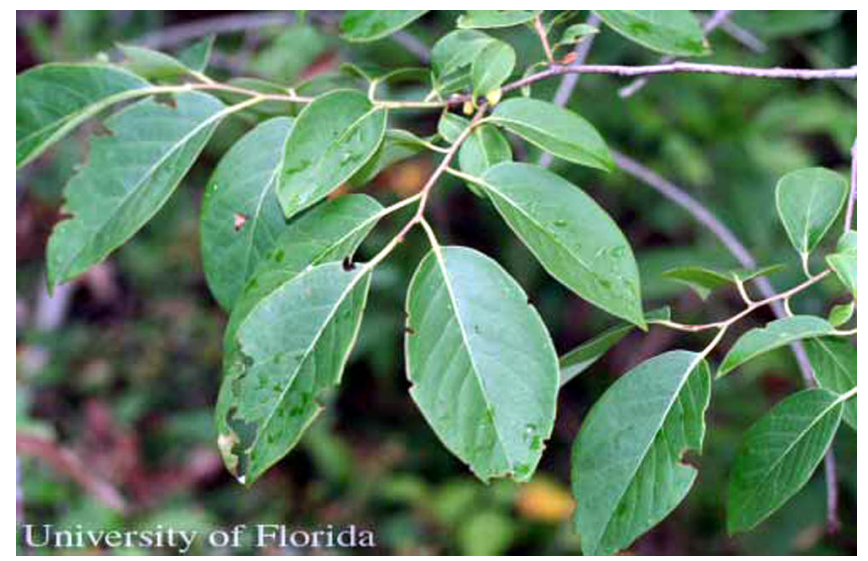

Figure 21. Persimmon, Diospyros virginiana L., a host of the luna moth, Actias luna (Linnaeus). Credits: D.W. Hall, University of Florida

ants and mice were deterred by the regurgitant of the polyphemus moth, Antheraea polyphemus (Cramer), and suggested that the clicking is a warning of the impending regurgitation.

When caterpillars are full-grown, they may begin to wander. The cocoon is spun among the leaves of the deciduous host plants but is not anchored to a twig as is the case with many polyphemus moth cocoons. Therefore, they fall to the ground in autumn (Holland 1968) as the leaves fall and are not commonly seen. Development from hatching to pupation takes a month or longer depending on temperature.

Luna moth caterpillars are never sufficiently common to cause significant damage to their host trees. 


\section{Selected References}

Brown SG, Boettner GH, Yack JE. 2007. Clicking caterpillars: acoustic aposematism in Antheraea polyphemus and other Bombycoidea. The Journal of Experimental Biology 210: 993-1005.

Covell CV. 2005. A Field Guide to Moths of Eastern North America. Special Publication Number 12. Virginia Museum of Natural History. Martinsville, Virginia. 496 pp.

Ferguson DC. 1972. In Dominick RB, Edwards CR, Ferguson DC, Franclemont JG, Hodges RW, Munroe EG. The Moths of America North of Mexico, fasc. 20.2B, Bombycoidea (in part). EW Classey, LTD. Middlesex, England.

Godfrey GL, Jeffords M, Appleby JE. 1987. Saturniidae (Bombycoidea). In Stehr FW. Immature Insects. Kendall/Hunt Publishing Company. Dubuque, Iowa. pp. 513-521.

Hilton HO. 1965. Pupal escape mechanism of certain saturniid moths. 48: 239-24.

Holland WJ. 1968. The Moth Book: A Guide to the Moths of North America. Dover Publications, Inc. New York. (First published in 1903 by Doubleday, Page and Company. New York) 479 pp.

Kellog SK, Fink LS, Brower LP. 2003. Parasitism of native luna moths, Actias luna (L.) (Lepidoptera: Saturniidae) by the introduced Compsilura concinnata (Meigen) (Diptera: Tachinidae) in central Virginia, and their hyperparasitism by trigonalid wasps (Hymenoptera: Trigonalidae). Environmental Entomology 32: 1019-1027.

Lindroth RL. 1989. Chemical ecology of the luna moth: Effects of host plant on detoxification enzyme activity. Journal of Chemical Ecology 15: 2019-2029.

Packard AS. 1914. Monograph of the Bombycine Moths of North America. Part 3. Memoirs of the National Academy of Science 12: $1-516$.
Peterson A. 1965. Some eggs of moths among the Sphingidae, Saturniidae, and Citheroniidae (Lepidoptera). 48: 213-219.

Powell JA. 2003. Lepidoptera (Moths, Butterflies). In VH Resh, Cardé RT, editors. Encyclopedia of Insects. Elsevier Science (USA) San Diego, California. pp. 631-663.

Priddle TR. 1967. Structures employed by Actias luna (Saturniidae) in effecting emergence from the cocoon. Journal of the Lepidopterists Society 21: 249-252.

Tietz HM. 1972. An Index to the Described Life Histories, Early Stages and Hosts of the Macrolepidoptera of the Continental United States and Canada. Part 1. The Allyn Museum of Entomology. Sarasota, Florida. (Distributed by Entomological Reprint Specialists. Los Angeles, California). 536 pp.

Tuskes PM, Tuttle JP, Collins MM. 1996. The Wild Silk Moths of North America: The Natural History of the Saturniidae of the United States and Canada. Cornell University Press. Ithaca, New York. $250 \mathrm{pp}$.

Villard P. 1975. Moths and How to Rear Them. Dover Publications, Inc. New York, New York. 242 pp.

Worth BC, Muller J. 1979. Captures of large moths by an UV light trap. Journal of the Lepidopterists' Society 33: 261-264.

Wright DA. 1967. The effects of photoperiod on the initiation of pupal diapause in the wild silkworm, Actias luna. Journal of the Lepidopterists Society 21: 255-258. 